\title{
Efektivitas Pendidikan Gizi dengan Media Kartu Edukasi Gizi terhadap Peningkatan Pengetahuan, Sikap dan Perilaku Makanan Jajanan Anak Sekolah Dasar
}

\author{
Witri Priawantiputri ${ }^{1}$, Mamat Rahmat ${ }^{2}$, Asep Iwan Purnawan ${ }^{3}$ \\ Jurusan Gizi, Politeknik Kesehatan Kemenkes Bandung, Indonesia \\ Email: wi3.afiqa@gmail.com
}

\begin{abstract}
Effectiveness of Nutrition Education Using Nutrition Card on Knowledge, Attitude, and Behavior of Choosing Snack Food among Elementary School Children. The safety of snack food for elementary school children is a major problem that becomes public attention. Nutrition education using attractive media such as nutrition cards is needed to improve children's knowledge and behavior on consuming a healthy snack. The purpose of this study was to identify the effectiveness of nutrition education using nutrition cards on increasing knowledge, attitudes, and behavior of Elementary School Children. A quasi-experimental of two groups with pretest and posttest study was conducted among 66 elementary school children in Elementary School 154 Citepus Bandung. The intervention was carried out for 3 weeks. The treatment group was given nutrition education using nutrition cards, meanwhile, the control group was given a lecture using powerpoint. Data analysis used in this study was the Wilcoxon test. To identify the effectiveness of increasing knowledge, attitudes, and behavior between the two groups, the Mann Whitney test was used. The results showed an increase in the score of students' knowledge, attitudes, and behavior after intervention among the treatment and control group (p-value $<0,05$ ). Based on the Mann-Whitney test, there was a significant difference between the increase in students' knowledge scores in the treatment group and the control group, the knowledge score in the treatment group was higher than the control group (p-value $<0,05$ ). The increase in students' attitudes and behavior scores between the treatment group and the control group was statistically no significant difference ( $\mathrm{p}$-value>0,05). Nutrition cards can be used as attractive media to increase children's knowledge and attitude toward choosing healthy snacks.
\end{abstract}

Keywords: Nutrition card, Nutrition education, Schoolchildren

\begin{abstract}
Abstrak: Efektivitas Pendidikan Gizi dengan Media Kartu Edukasi Gizi terhadap Peningkatan Pengetahuan, Sikap dan Perilaku Makanan Jajanan Anak Sekolah Dasar. Keamanan makanan ringan untuk anak-anak sekolah dasar adalah masalah utama yang menjadi perhatian publik. Pendidikan gizi menggunakan media yang menarik seperti kartu edukasi gizi diperlukan untuk meningkatkan pengetahuan dan perilaku anak-anak dalam mengkonsumsi makanan ringan yang sehat. Tujuan penelitian mengidentifikasi efektivitas pendidikan gizi menggunakan kartu edukasi gizi pada peningkatan pengetahuan, sikap, dan perilaku anak-anak Sekolah Dasar. Sebuah eksperimen semu dari dua kelompok dengan studi pre-test dan post-test dilakukan di antara 66 anak sekolah dasar di SDN 154 Citepus Bandung. Intervensi dilakukan selama 3 minggu. Kelompok perlakuan diberikan edukasi gizi menggunakan kartu gizi, sedangkan kelompok kontrol diberi ceramah menggunakan powerpoint. Analisis data yang digunakan dalam penelitian ini adalah tes Wilcoxon. Untuk mengidentifikasi efektivitas peningkatan pengetahuan, sikap, dan perilaku antara kedua kelompok menggunakan uji Mann Whitney. Hasil penelitian menunjukkan peningkatan skor pengetahuan, sikap, dan perilaku siswa setelah intervensi di antara kelompok perlakuan dan kontrol ( $p$-value<0,05). Berdasarkan uji Mann-Whitney, ada perbedaan yang signifikan antara peningkatan skor pengetahuan siswa pada kelompok perlakuan dan kelompok kontrol, skor pengetahuan pada kelompok perlakuan lebih tinggi daripada kelompok kontrol ( $p$-value $<0,05)$. Peningkatan nilai sikap dan perilaku siswa antara kelompok perlakuan dan kelompok kontrol secara statistik tidak ada perbedaan yang signifikan ( $p$-value $>0,05)$. Kartu edukasi gizi dapat digunakan sebagai media yang menarik untuk meningkatkan pengetahuan dan sikap anak-anak dalam memilih makanan ringan yang sehat.
\end{abstract}

Kata kunci: Kartu edukasi gizi, Pendidikan gizi, Anak sekolah dasar 


\section{PENDAHULUAN}

Anak Sekolah Dasar merupakan siklus yang penting dalam kehidupan dimana mereka akan tumbuh dengan optimal jika didukung oleh makanan dengan gizi seimbang. Sebagian besar makanan anak sekolah berasal dari konsumsi makanan jajanan di lingkungan sekolah (Pertiwi, 2016). Peningkatan konsumsi makanan jajanan di Amerika mencapai $98 \%$ dari tahun 2003-2006 (Popkin, 2010). Sedangkan di Asia peningkatan konsumsi makanan jajanan di tahun 1991 sebesar 15,4\% menjadi 20,6\% pada tahun 2004 (Wang, 2008). Sedangkan di Indonesia sebanyak $78 \%$ anak sekolah jajan di lingkungan sekolah baik di kantin maupun dari penjaja sekitar sekolah (Robi, 2011).

Di sisi lain, sebagian besar anak sekolah tidak memiliki cukup pengetahuan dalam memilih makanan jajanan hingga akan mempengaruhi sikap dan perilakunya dalam memilih makanan jajanan (Widiyaningsih, 2018). Sikap anak tentang jajanan sehat sangat perlu ditingkatkan, dengan demikian anak akan mengetahui mana jajanan yang mengandung gizi baik dan mana jajanan yang tidak baik untuk dikonsumsi (Wulandari, 2016).

Oleh karena itu pengetahuan keamanan makanan jajanan anak sekolah dasar merupakan masalah yang perlu menjadi perhatian karena makanan tersebut berisiko terhadap cemaran biologis, fisik maupun kimiawi yang membahayakan kesehatan anak (Suci, 2009). Survey yang dilakukan Badan Pengawas Obat dan Makanan (BPOM) tahun 2013 di 30 kota di Indonesia menunjukkan dari 7.200 sampel makanan jajanan anak sekolah dasar yang diambil dari 990 pedagang makanan ternyata ditemukan 1.720 makanan jajanan (23,89\%) tidak memenuhi syarat kesehatan (Badan POM, 2013). Penyebab sampel tidak memenuhi syarat antara lain karena menggunakan bahan berbahaya yang dilarang untuk pangan, menggunakan bahan tambahan pangan melebihi batas maksimal, mengandung cemaran logam berat melebihi batas maksimal, dan kualitas mutu mikrobiologis yang tidak memenuhi syarat (Badan POM, 2013).

Hasil penelitian mengenai makanan jajanan pada anak usia Sekolah Dasar yang dilakukan di salah satu Sekolah Dasar Negeri Kota Bandung menyebutkan pemilihan makanan jajanan yang dilakukan oleh siswa di sekolah berada pada pemilihan yang tidak baik dengan presentase pemilihan baik $(42,0 \%)$ dan tidak baik (57,3\%) (Iklima, 2017).

Upaya yang dapat dilakukan untuk menghindari anak sekolah dasar dari bahaya makanan jajanan yang tidak sehat adalah dengan memberikan pendidikan gizi. Pendidikan tentang makanan sehat selama masa anak-anak tidak hanya mencegah beberapa penyebab penyakit utama dan kematian, tetapi juga dapat menurunkan biaya kesehatan dan dapat meningkatkan kualitas hidup manusia (CDC, 2011).

Pendidikan gizi di lingkungan sekolah dapat memberikan pengaruh positif terhadap pengetahuan, sikap, dan tindakan anakanak.Metode dan media yang digunakan dalam pemberian edukasi gizi menjadi faktor yang penting dalam keberhasilan program pendidikan gizi (Kostanjevec, et al., 2011). Penggunaan Media dapat membantu menstimulasi indera mata (penglihatan) pada waktu terjadinya proses pendidikan. Alat bantu berfungsi untuk membantu dan memperagakan sesuatu dalam proses pendidikan agar anak dapat lebih mudah memahami apa yang disampaikan oleh seseorang.

Salah satu media yang dapat digunakan dalam memberikan pendidikan gizi adalah kartu edukasi gizi. Kartu ini berisi pesan singkat mengenai keamanan makanan jajanan yang disertai dengan gambar yang menarik. Sehingga dengan adanya media ini akan menarik perhatian siswa dan memudahkan dalam memahami materi pendidikan gizi yang diberikan. Penelitian Wahyuningsih (2016) terhadap anak kelas 5 di SDN Keputih Surabaya yang diberikan intervensi pendidikan gizi jajanan sehat dengan Nutrition Card terjadi peningkatan pengetahuan dari $7,95 \pm 2,06$ menjadi $8,92 \pm 0,99$ dengan rata-rata peningkatan sebesar 1,33+1,07 sedangkan anakanak yang diberikan pendidikan gizi dipapan tulis peningkatan pengetahuannya lebih rendah, yaitu dari 7,62 $\pm 1,98$ menjadi $7,7 \pm 1,78$ dengan rata-rata peningkatan sebesar $0,08 \pm 0,2$.

Penelitian lainnya yang dilakukan oleh Briawan (2016) dan PT. Unilever Indonesia terhadap 1.600 anak SD kelas 5 dari 13 Kabupaten/Kota dari 8 Provinsi di Indonesia, tingkat pengetahuan baik, sikap baik dan praktik jajanan baik sebelum dilakukan edukasi gizi dengan media flipchart, poster dan audio kinetik untuk senam masing-masing sebesar 50,9\%, $82,9 \%$ dan $17,9 \%$. Setelah dilakukan edukasi selama 21 hari terjadi peningkatan proporsi pengetahuan anak dengan tingkat pengetahuan baik sebesar $16,2 \%$, peningkatan proporsi anak yang memiliki sikap jajanan yang baik sebesar $7,3 \%$, dan peningkatan proporsi anak dalam praktik memilih jajanan yang baik sebesar $2,7 \%$ (Briawan, 2016). 
Berdasarkan latar belakang masalah menunjukkan pentingnya peningkatan pengetahuan, sikap dan perilaku tentang jajanan sehat pada Anak Sekolah Dasar. Dengan adanya peningkatan pengetahuan diharapkan siswa mempunyai sikap dan perilaku yang positif tentang jajanan sehat.Oleh karena itu, peneliti tertarik untuk meneliti lebih lanjut tentang efektivitas pendidikan gizi dengan media kartu edukasi gizi terhadap peningkatan pengetahuan, sikap dan perilaku makanan jajanan anak Sekolah Dasar.

\section{METODE}

Rancangan dalam penelitian ini adalah quasi eksperiment with pre-test dan post-test control group. Desain penelitian ini digunakan untuk membandingkan hasil intervensi dari pendidikan gizi yang diberikan pada dua kelompok, yaitu kelompok perlakuan yang diberikan pendidikan gizi dengan media kartu edukasi gizi dan dengan kelompok kontrol yang hanya diberikan edukasi gizi dengan metode ceramah saja. Pengukuran dilakukan sebanyak dua kali, yaitu sebelum diberikan intervensi dan tiga minggu setelah diberikan intervensi. Intervensi dilakukan sebanyak 3 kali dengan jarak satu minggu, dalam 1 minggu terdapat 1 kali pertemuan dengan masing-masing pertemuan menghabiskan waktu kurang lebih 30 menit. Penelitian dilakukan pada bulan Juli sampai September 2018 di SD Negeri 154 Citepus Bandung.

Populasi penelitian ini siswa kelas 5 di SD Negeri 154 Citeupus Bandung yang berjumlah 196 siswa yang tersebar di lima kelas. Alasan pemilian siswa kelas SD adalah karena siswa yang duduk di kelas 5 sudah memiliki tingkat pemahaman yang lebih baik jika dibandingkan dengan kelas di bawahnya dan sudah mampu meneruskan materi yang sudah diperoleh kepada keluarga ataupun teman sebayanya (Contento, 2011). Sampel pada peneitian ini berjumlah 66 siswa dari dua kelas yang dipilih secara random. Kelas intervensi terdapat 33 siswa sedangkan kelas kontrol juga 33 siswa. Berikut adalah alur dari penelitian:

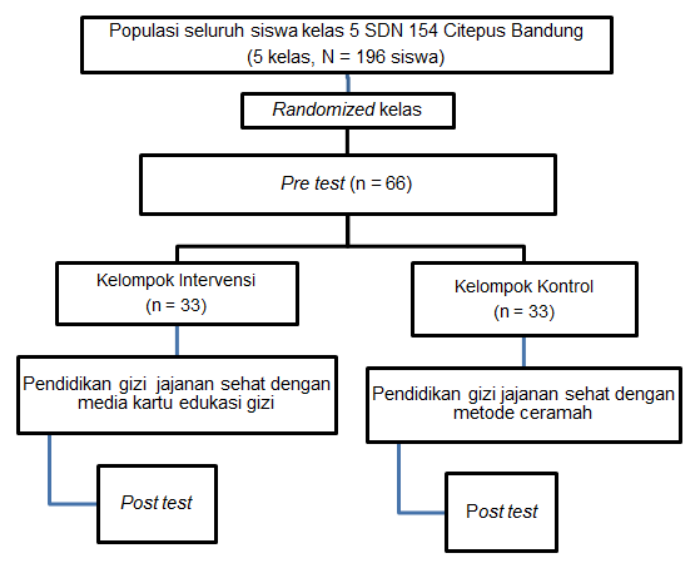

Gambar 1. Diagram Alur Penelitian

Metode pengumpulan data pada penelitian ini adalah pengisian kuesioner oleh sampel pada saat pretest dan post test untuk mendapatkan data pengetahuan, sikap dan perilaku makanan jajanan. Kuesioner pengetahuan, sikap dan perilaku makanan jajanan di uji coba dan divalidasi sebelum pengambilan data. Materi intervensi yang terdapat dalam kartu edukasi gizi dan powerpoint meliputi; pengertian makanan jajanan sehat, ciri-ciri makanan yang bebas dari cemaran kimia, ciri-ciri makanan yang mengandung pewarna buatan, hygiene dan sanitasi makanan, cara pengujian makanan yang mengandug boraks, contoh makanan yang mengandung pewarna buatan, bahaya yang ditimbulkan makanan yang tidak sehat, tips memilih jajanan yang sehat dan aman, contoh jajanan yang tidak sehat.

Pengolahan data meliputi editing, coding, entry dan cleaning. Data karakteristik sampel meliputi jenis kelamin dikelompokkan menjadi 2 kategori, yaitu laki-laki dan perempuan.Skor pengetahuan, sikap dan perilaku sebelum dan sesudah intervensi diperoleh dengan cara menghitung jumlah jawaban yang benar yang diisi oleh sampel dibagi jumlah soal dikali 100 sehingga didapatkan skor pengetahuan, sikap dan perilaku siswa terendah 0 dan tertinggi 100 . Seluruh proses pengolahan data dilakukan menggunakan program komputer.

Data skor pengetahuan, sikap dan perilaku konsumsi makanan jajanan sehat hasil Pre-test dan post-test sebelum dianalisis lebih lanjut dilakukan uji normalitas data menggunakan Uji Kolmogorov Smirnov dengan probabilitas >0,05. Untuk melihat perbedaan nilai skor pengetahuan, sikap dan perilaku siswa akan makanan jajanan pada kelompok perlakuan maupun kelompok control dilakukan uji Wilcoxon test. Untuk melihat efektifitas penggunaan media kartu edukasi gizi dilakukan uji non parametrik MannWhitney test. 
Penelitian ini telah mendapat persetujuan etik penelitian dari Komisi Etik Penelitian Kesehatan (ethical clearance) Politeknik Kesehatan Kemenkes Bandung Nomor: 29/KEPK/PE/V/2018.

\section{HASIL}

Pengamatan yang dilakukan di SDN 154 Citepus banyak minuman dan makanan jajanan yang dijual di sekitar sekolah. Makanan jajanan di sekitar sekolah berupa aneka minuman kemasan dan seduh, aneka gorengan, makanan dengan warna-warna mencolok. Makanan yang dijual, secara fisik terlihat berbahaya, seperti penggunaan saos yang berwarna merah mencolok dan minyak yang berwarna hitam pekat. Wawancara langsung terhadap beberapa anak yang sedang jajan alasan anak membeli makanan jajanan tersebut karena harganya murah, menarik dan enak. Informasi yang didapatkan dari kepala Sekolah sebagian besar siswa tidak membawa bekal makan ke sekolah, sehingga setiap pagi dan pada saat jam istirahat mereka membeli makanan jajanan yang ada dilingkungan sekolah.

\section{Karakteristik Sampel Berdasarkan Jenis Kelamin}

Tabel 1. Karakteristik Sampel Berdasarkan Jenis Kelamin

\begin{tabular}{lcccr}
\hline \multirow{2}{*}{$\begin{array}{c}\text { Jenis } \\
\text { Kelamin }\end{array}$} & \multicolumn{4}{c}{ Kelompok } \\
\cline { 2 - 5 } & \multicolumn{2}{c}{ Perlakuan } & \multicolumn{2}{c}{ Kontrol } \\
\cline { 2 - 5 } & n & \% & n & \multicolumn{1}{c}{$\%$} \\
\hline Laki-laki & 17 & 50,00 & 22 & 64,75 \\
Perempuan & 17 & 50,00 & 12 & 35,25 \\
Total & 34 & 100,00 & 34 & 100,00 \\
\hline
\end{tabular}

Pada tabel 1, jumlah sampel dengan jenis kelamin laki-laki dan perempuan pada kelompok perlakuan adalah sama, masing-masing berjumlah 17 siswa (50\%). Sedangkan pada kelompok kontrol jumlah siswa laki-laki lebih tinggi yaitu 22 siswa $(64,75 \%)$ dibandingkan dengan siswa perempuan berjumlah 12 siswa $(32,25 \%)$.

Gambaran Pengetahuan, Sikap dan Perilaku Makanan Jajanan Sampel Sebelum Perlakuan

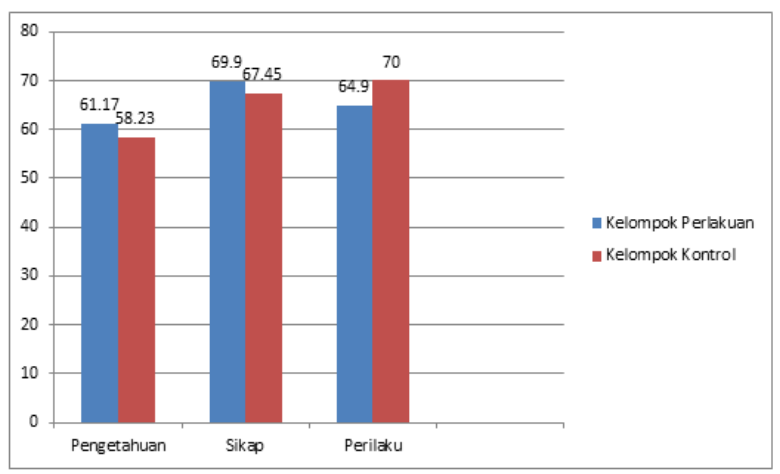

Gambar 1. Gambaran Pengetahuan, Sikap dan Perilaku Makanan Jajanan Sampel Sebelum Perlakuan

Gambar 1 menunjukkan skor pengetahuan, sikap, dan perilaku makanan jajanan sampel pada kelompok perlakuan dan kontrol sebelum intervensi mempunyai nilai yang tidak berbeda jauh. Setelah dilakukan analisis statistik diketahui tidak ada perbedaan yang signifikan skor pengetahuan, sikap, dan perilaku antara kelompok perlakuan dan kelompok kontrol dengan nilai $p$-value 0,$111 ; 0,342$; dan 0,220 .

Gambaran Pengetahuan, Sikap dan Perilaku Makanan Jajanan Sampel Sebelum dan Sesudah Perlakuan

Tabel 2. Gambaran Pengetahuan, Sikap dan Perilaku Makanan Jajanan Sampel Sebelum dan Sesudah Perlakuan

\begin{tabular}{ccccc}
\hline \multirow{2}{*}{ Variabel } & \multicolumn{2}{c}{$\begin{array}{c}\text { Kelompok } \\
\text { Perlakuan }\end{array}$} & \multicolumn{2}{c}{$\begin{array}{c}\text { Kelompok } \\
\text { Kontrol }\end{array}$} \\
\cline { 2 - 5 } & $\begin{array}{c}\text { Median } \\
\text { Min-max })\end{array}$ & $\begin{array}{c}\text { Nilai } \boldsymbol{p} \text { - } \\
\text { value }\end{array}$ & $\begin{array}{c}\text { Median } \\
\text { Min-max })\end{array}$ & $\begin{array}{c}\text { Nilai } \boldsymbol{p} \text { - } \\
\text { value }\end{array}$ \\
\hline $\begin{array}{c}\text { Pengetahuan } \\
\text { pre-test }\end{array}$ & $66,7(26,6-80,0)$ & & & \\
post-test & $80,0(46,6-100,0)$ & 0,000 & $60,0(26,7-80,0)$ & 0,001 \\
$\begin{array}{c}\text { Sikap } \\
\text { pre-test }\end{array}$ & $73,3(33,3-93,3)$ & & $66,7(26,7-93,3)$ & \\
post-test & $80,0(53,3-93,3)$ & 0,003 & $70,0(40,0-93,3)$ & 0,002 \\
$\begin{array}{c}\text { Perilaku } \\
\text { pre-test }\end{array}$ & $66,7(33,3-93,3)$ & & $80,0(20,0-93,3)$ & \\
post-test & $80,0(46,7-93,3)$ & 0,000 & $73,3(40,0-93,3)$ & 0,030 \\
\hline
\end{tabular}


Tabel 2 menunjukkan nilai median skor pengetahuan pada kelompok perlakuan mengalami peningkatan setelah perlakuan sebesar 13,33. Dari hasil uji Wilcoxon dapat diketahui bahwa secara statistik ada perbedaan yang bermakna nilai median skor pengetahuan sebelum dan sesudah diberikan edukasi gizi menggunakan media kartu edukasi gizi dengan nilai $p$-value 0,000 . Pada kelompok kontrol juga terjadi peningkatan nilai median pengetahuan sebesar 6,67 dengan nilai $p$-value 0,001. Median skor sikap pada kelompok perlakuan mengalami peningkatan sebesar 6,7, pada kelompok kontrol juga mengalami peningkatan lebih besar sebanyak 10. Berdasarkan uji Wilcoxon pada kelompok perlakuan maupun kelompok kontrol ada perbedaan yang bermakna nilai median skor sikap sebelum dan sesudah pemberian edukasi gizi dengan nilai $p$-value 0,003 dan 0,002 .

Nilai median skor perilaku pada kelompok perlakuan mengalami peningkatan sebesar 13,3, pada kelompok kontrol juga mengalami peningkatan lebih besar sebanyak 6,7. Berdasarkan uji Wilcoxon pada kelompok perlakuan maupun kelompok kontrol ada perbedaan yang bermakna nilai median skor sikap sebelum dan sesudah pemberian edukasi gizi dengan nilai $p$-value 0,000 dan 0,003 . Secara garis besar skor pengetahuan, sikap dan perilaku siswa sebelum dan sesudah diberikan penyuluhan gizi dengan media kartu edukasi gizi maupun secara konvensional ada perbedaan yang bermakna.

Efektivitas Pendidikan Gizi dengan Menggunakan Kartu Edukasi Gizi dan Ceramah terhadap Peningkatan Pengetahuan, Sikap, dan Perilaku Makanan Jajanan Sehat

Tabel 3. Perbedaan Perubahan Skor Pengetahuan, Sikap dan Perilaku setelah Pemberian Edukasi Gizi antara Kelompok Perlakuan dan Kelompok Kontrol

\begin{tabular}{llccc}
\hline \multicolumn{1}{c}{$\begin{array}{c}\text { Nama } \\
\text { Variabel }\end{array}$} & Kelompok & n & $\begin{array}{c}\text { Mean } \\
\text { Rank }\end{array}$ & $\begin{array}{c}\boldsymbol{p} \text { - } \\
\text { value }\end{array}$ \\
\hline $\begin{array}{l}\text { Perubahan } \\
\text { pengetahuan }\end{array}$ & Perlakuan & 33 & 38,58 & 0,031 \\
\hline Perubahan & Perlakuan & 33 & 28,42 & \\
Sikap & Kontrol & 33 & 34,53 & 0,661 \\
\hline $\begin{array}{l}\text { Perubahan } \\
\text { Perilaku }\end{array}$ & Perlakuan & 33 & 36,39 & 0,214 \\
\hline
\end{tabular}

Untuk menguji ada tidaknya perbedaan skor peningkatan pengetahuan, sikap dan perilaku pada kelompok perlakuan yaitu siswa yang diberikan pendidikan gizi dengan kartu edukasi dan siswa yang diberikan pendidikan gizi dengan metode ceramah dan tanya jawab, dilakukan uji statistik non parametrik MannWhitney test, alasan menggunakan uji ini karena hasil uji normalitas data distribusi data tidak normal.

Tabel 3 menunjukkan perubahan skor pengetahuan setelah diberikan edukasi gizi antara kelompok perlakuan dengan kelompok kontrol secara statistik bermakna, dimana nilai $p$ value<0,05. Mean rank peningkatan skor pengetahuanpada kelompok perlakuan sebesar 38,58 lebih tinggi dibandingkan dengan kelompok kontrol yaitu mean rank sebesar 28,42. Jika dilihat dari perbedaan mean rank skor pemberian pendidikan gizi menggunakan kartu edukasi gizi lebih efektif dalam meningkatkan pengetahuan makanan jajanan dibandingkan dengan menggunakan metode ceramah tanya jawab.

Pada tabel 3 terlihat bahwa nilai $p$-value sikap dan perilaku siswa antara kelompok perlakuan dan kelompok kontrol setelah diberikan intervensi secara statistik semuanya tidak bermakna, $p$-value $>0,05$. Kesimpulannya tidak ada perbedaan yang signifikan sikap dan perilaku setelah diberikan intervensi antara kelompok perlakuan dan kelompok kontrol. Masing-masing peningkatan mean rank sikap maupun perilaku pada kelompok perlakuan dan kelompok kontrol terlihat tidak berbeda.

\section{PEMBAHASAN}

Pendidikan atau penyuluhan gizi adalah pendekatan edukatif untuk menghasilkan perilaku individu atau masyarakat yang diperlukan dalam meningkatkan perbaikan pangan dan status gizi (Claire, 2010). Harapan dari upaya ini adalah siswa dapat memahami pentingnya makanan dan gizisehingga dapat bersikap dan bertindak mengikuti norma-norma gizi, yang diawali dengan peningkatan pengetahuan hingga perubahan sikap dan perilaku. Pada penelitian ini (Tabel 2) ditemukan adanya perbedaan yang bermakna skor pengetahuan, sikap dan perilaku sampel akan makanan jajanan setelah diberikan pendidikan gizi pada kelompok perlakuan maupun kelompok kontrol.

Penelitian sebelumnya yang dilakukan oleh Dodik Briawan bekerjasama dengan PT Unilever Indonesia terhadap 1.600 anak SD kelas 5 di 8 Provinsi di Indonesia, setelah diberikan edukasi gizi dengan media flipchart, poster dan audio kinetik selama 21 hari terjadi peningkatan jumlah proporsi pengetahuan anak dengan tingkat pengetahuan baik sebesar $16,2 \%$, peningkatan 
proporsi anak yang memiliki sikap jajanan yang baik sebesar $7,3 \%$, dan peningkatan proporsi anak dalam praktik memilih jajanan yang baik sebesar 2,7\% (Briawan, 2016). Penelitian lain menunjukkan kenaikan skor sikap responden baik sebanyak $10 \%$ setelah diberikan pendidikan gizi. Hasillainnya menunjukkan perilaku anak sebelum dilakukan penyuluhan yaitu sebesar $66,7 \%$ yang mempunyai perilaku yang baik, dan $33,3 \%$ mempunyai perilaku yang cukup. Peningkatan pengetahuan, sikap dan perilaku anak meningkat disebabkan adanya penambahan informasi yang dilakukan kepada anak melalui pendidikan gizi (Ismail, 2018).

Hasil penelitian ini dan penelitian sebelumnya menunjukkan trend yang sama bahwa pendidikan gizi yang diberikan dengan penggunaan media kreatif maupun dengan cara konvensional dapat meningkatkan pengetahuan, sikap, dan perilaku makanan jajanan pada Anak Sekolah. Hal ini juga sesuai dengan yang dilaporkan oleh Hayati (2009) bahwa terdapat pengaruh edukasi tentang jajanan sehat terhadap peningkatan pengetahuan positif dalam menentukan jajanan sehat.

Faktor lain yang mempengaruhi adalah daya ingat atau daya serap sehingga pengetahuan anak tersebut cukup baik. Hakim (2005) melaporkan bahwa daya ingat sangat mempengaruhi keberhasilan belajar seseorang. Skor jawaban responden hasil pengetahuan dan perilaku anak selaras saling berhubungan satu sama lain. Hal ini diperkuat oleh hasil penelitian yang dilaporkan oleh Triasari (2015) bahwa adanya hubungan pengetahuan tentang pemilihan makanan jajanan dengan perilaku anak dalam memilih makanan jajanan.

Pada Tabel 3 menunjukkan bahwa pemberian pendidikan gizi dengan menggunakan media kartu edukasi gizi lebih efektif meningkatkan pengetahuan siswa dibandingkan dengan pendidikan gizi dengan cara konvensional (hanya ceramah). Hasil ini sesuai dengan hasil penelitian yang dilakukan oleh Wahyuningsih (2015) terhadap anak kelas 5 di SDN Keputih Surabaya yang diberikan intervensi pendidikan gizi jajanan sehat dengan Nutrition Card selama 1 bulan terjadi peningkatan pengetahuan dari $7,95+2,06$ menjadi $8,92+0,99$ dengan rata-rata peningkatan sebesar 1,33+1,07 sedangkan anakanak yang diberikan pendidikan gizi dipapan tulis peningkatan pengetahuannya lebih rendah, yaitu dari 7,62 $\pm 1,98$ menjadi $7,7 \pm 1,78$ dengan rata-rata peningkatan sebesar $0,08 \pm 0,2$.

Hal ini menunjukkan bahwa dengan adanya media edukasi yang menarik dapat meningkatkan proses pembelajaran sehingga materi dapat tersampaikan dengan baik. Hasil penelitian ini sejalan dengan penelitian sebelumnya dari Hamida, dkk (2012) menunjukkan peningkatan pengetahuan siswa setelah diberi penyuluhan tentang keamanan makanan jajanan dengan media komik.

Media kartu edukasi gizi ini dapat membantu menstimulasi indera mata (penglihatan) pada waktu terjadinya proses pendidikan. Media ini memiliki keunggulan karena dapat menyampaikan pengertian atau informasi dengan cara yang lebih konkret, daripada disampaikan hanya dengan kata-kata yang diucapkan tanpa adanya alat bantu dalam penyampaian informasi pada anak. Penggunaan media pendidikan sangat membantu dalam proses pembelajaran. Di samping dapat meningkatkan motivasi, media pendidikan juga dapat membantu meningkatkan pemahaman siswa terhadap materi yang disampaikan (Hamida, dkk., 2012).

Penelitian lainnya juga menyebutkan terdapat perbedaan tingkat pengetahuan yang signifikan antara kelompok yang diberikan pendidikan gizi dengan bantuan media kubus bergambar dibandingkan dengan tanpa media. Sebanyak 73,6\% sampel menyatakan mudah memahami materi yang disampaikan dengan media tersebut (Hidayat, 2013). Penelitian yang dilakukan oleh Zulaekah (2012) juga menunjukkan terjadinya peningkatan pengetahuan anak sekolah dasar setelah diberikan intervensi pendidikan gizi dengan media booklet.

Proses pendidikan dengan menggunakan alat peraga (media) berarti mencoba memerlihatkan situasi yang hampir sama dengan realita kepada sasaran. Dengan demikian, sasaran akan lebih cepat memahami pesan-pesan yang disampaikan (Hidayat, 2013). Dengan demikian pendidikan dengan menggunakan media kartu edukasi gizi ini dapat meningkatkan proses belajar siswa, sehingga pesan yang diberikan dapat diterima dengan baik oleh siswa. Kelebihan dari media ini adalah lebih mengutamakan unsur permainan yang sesuai dengan karakteristik anak sekolah dasar yang senang bermain dan penggunaan kartu sudah tidak asing lagi di kalangan anak-anak sehingga lebih mudah dalam memainkannya.

Namun pemberian pendidikan gizi dengan menggunakan media kartu edukasi gizi ini ternyata belum efektif untuk meningkatkan sikap dan perilaku makanan jajanan pada Anak Sekolah (p-value $>0,005)$. Hal ini mungkin berkaitan dengan edukasi gizi yang diberikan merupakan faktor yang berasal dari luar individu, berupa stimulus untuk mengubah dan membentuk sikap anak dalam memilih makanan jajanan yang 
sehat (Azwar, 2013). Oleh karena itu masih banyak faktor dari luar maupun dalam lainnya yang dapat mempengaruhi sikap seseorang. Sikap sendiri belum merupakan suatu tindakan atau aktivitas namun merupakan predisposisi tindakan suatu perilaku. Sehingga diharapkan dengan peningkatan sikap anak pada pemilihan jajanan yang baik dapat mengubah perilaku konsumsi jajanan anak.

Pemberian edukasi dengan menggunakan media kartu edukasi gizi ini diharapkan dapat menjadi faktor penguat (reinforcing factor), yaitu faktor yang mendorong atau memperkuat terjadinya perilaku. Menurut Notoatmodjo (2010) perilaku adalah semua kegiatan atau aktivitas manusia, baik dapat diamati langsung maupun yang tidak dapat diamati oleh pihak luar. Perilaku merupakan respons atau reaksi seseorang terhadap stimulus (rangsangan dari luar). Namun dalam memberikan respons sangat tergantung pada karakteristik atau faktor-faktor lain dari orang yang bersangkutan. Faktor-faktor yang membedakan respons terhadap stimulus yang berbeda disebut determinan perilaku. Pada penelitian ini pemberian pendidikan gizi dengan menggunakan kartu edukasi diharapkan dapat memberikan stimulus yang efektif pada Anak dalam memilih makanan jananan yang sehat. Namun, hasil penelitian menunjukkan tidak adanya perbedaan skor peningkatan sikap dan perilaku pada kelompok perlakuan maupun kelompok kontrol. Hal ini menunjukkan bahwa edukasi gizi yang diberikan baru mencapai ranah

\section{DAFTAR PUSTAKA}

Azwar, S. (2013). Perilaku Manusia: Teori dan Pengukurannya. Yogyakarta: Pustaka Pelajar.

Badan Pengawas Obat dan Makanan (BPOM) R.I. (2013). Laporan Kinerja Badan Pengawas Obat danMakanan R.I tahun 2013. Jakarta: Kepala Badan Pengawas Obat dan Makanan R.I.

Badan Pengawas Obat dan Makana (BPOM) RI. (2013). Pedoman Pangan Jajanan Anak Sekolah Untuk Pencapaian Gizi Seimbang: Untuk Orang Tua, Guru dan Pengelola Kantin. Direktorat Standardisasi Produk Pangan. Jakarta: Deputi Bidang Pengawasan Keamanan Pangan dan Bahan Berbahaya.

Briawan, Dodik. (2016). Perubahan Perilaku Perilaku, dan Praktik Jajanan Anak Sekolah Dasar Peserta Program Edukasi Pangan Jajajan. Jurnal Gizi Pangan, pengetahuan (knowledge) belum mencapai ranah tindakan (practice).

Beberapa penelitian di berbagai negara juga menemukan hal yang serupa bahwa pendidikan gizi sangat efektif untuk merubah pengetahuan dan sikap anak terhadap makanan, tetapi kurang efektif untuk merubah perilaku praktek makan (Februhartanty, 2005). Perilaku anak dalam memilih makanan jajanan dapat dipengaruhi oleh beberapa faktor salah satunya adalah meniru perilaku teman sebayanya. Hal ini sejalan dengan penelitian yang telah dilaporkan oleh Febriyanto (2016), bahwa salah satu faktor yang memiliki pengaruh besar terhadap terjadinya perilaku seseorang yaitu faktor sosio psikologis. Faktor lain sosio psikologis yang terdiri dari sikap, emosi, kepercayaan, kebiasaan, dan kemauan. Triasari (2015) juga melaporkan bahwa pengetahuan yang baik belum tentu sejalan dengan perilaku anak dalam kehidupan sehari-hari.

\section{SIMPULAN}

Kartu edukasi gizi dapat digunakan sebagai media kreatif dalam memberikan pendidikan gizi di sekolah khususnya mengenai makanan jajanan. Pemberian edukasi jajanan sehat bagi siswa lainnya sebaiknya terus dilakukan secara berkelanjutan dan bertahap sehingga dicapai perubahan pengetahuan, sikap dan sampai praktik keseharian siswa.
Volume 11, No. 3 November 2016, 11 (3) : 201-210.

Centers for Disease Control and Prevention (CDC). (2011). School Health Guidelines to Promote Healthy Eating and Physical Activity.

http://www.cdc.gov/mmwr/preview/mmwr html/rr6005a1.htm. Diakses pada tanggal 6 Oktober 2017.

Claire E Orummound. (2010). Using nutritioneducation and cooking clasess in primaryschools to encourge healthy eating. Journal of Student Wellbeing, 4 (2): 43-54.

Contento, IR. (2011). Nutrition Education Lingking Research, Theory and Practice (Second Edition). Sudbury: Jhon and Bartlett Publishers.

Febriyanto, M.Aminuddin. (2016). Hubungan antara Pengetahuan dan Sikap Dengan Perilaku Konsumsi Jajanan Sehat di MI 
Sulaimaniyah Mojoagung Jombang. [Skripsi]. Surabaya: Universitas Airlangga FKM.

Februhartanty, J. (2005). Nutrition Education: It Has Never Been an Easy Case for Indonesia. Food and Nutrition Bulletin. 26(2): S267-S274.

Hamida, K., Zulaekah, S., Mutalazimah. (2012). Penyuluhan Gizi dengan Media Komik untuk Meningkatkan Perilaku Tentang Keamanan Makanan Jajanan. Jurnal Kesehatan Masyarakat, 8(1), 67-73.

Hakim, T. (2005). Belajar Secara Efektif. Pustaka Pembangun Swadaya Nusantara, Jakarta.

Hayati, M. (2009). Pengaruh Peer Edukasi Tentang Jajanan Sehat Terhadap Perilaku Anak UsiaSekolah di Kota Lhokseumawe Nanggroe Aceh Darussalam. [Skripsi]. Jakarta: Program Studi Magister Ilmu Keperawatan. Fakultas Ilmu Keperawatan. Universitas Indonesia.

Hidayat, H. (2013). Pengaruh Pendidikan GiziMelalui Diskusi dan Permainan Edukatif Kubus Bergambar terhadap Perilaku Gizi Seimbang Siswa Sekolah Dasar Kabupaten Bogor. [Skripsi]. Bogor: Intstitut Pertanian Bogor. Diakses dari http://repository.ipb.ac.id/handle/12345678 9/66295.

Iklima, Nurul. (2017). Gambaran Pemilihan Makanan Jajanan Pada Anak Usia Sekolah Dasar. Jurnal Keperawatan BSI, Vol.5 No.1 April 2017.

Ismail, Anshrulloh, dan Sri Rejeki. (2018). Perbedaan Antara Pengetahuan, Sikap Dan Perilaku Anak Tentang Konsumsi Jajanan Sehat (Sebelum Dan Sesudah Penyuluhan) di SD Negeri 4 Poasia Kecamatan Kambu Kota Kendari. J. Sains dan Teknologi Pangan Vol. 3, No. 1, P. 1036-1051, Th. 2018.

Kostanjevec, S., Jerman, J., Koch, V. (2011). The Effects of Nutrition Education on 6th Graders Knowledge of Nutrition in Nineyear Primary Schools in Slovenia. Eurasia Journal of Mathematics, Science \& Technology Education, 7(4), 243-252.

Notoatmodjo, Soekidjo. (2010). Ilmu Perilaku Kesehatan. Jakarta: Rineka Cipta.

Popkin, Barry M., \& Piernas, Carmen. (2010). Trends In Snacking Among U.S. Children. Health Affairs 2010: 29, No. 3. Diakses 12 November 2015. http://www.banpac.org/pdfs/sfs/2

010/snack_article_popkin_11_04_10.pdf

Robi, Arnie. (2011). Sumbangsih pada Keamanan Pangan.

http://www.masyarakatmandiri.org/artikel397-sumbangsih-pada-keamanan-panganhtml.

Pertiwi, Gagat Ekasakti., Dwija I Dewa Alit., Soewardikoen Didit Widiatmoko. (2016). Komik Edukasi Jajanan Sehat. Demandia, Vo.01 No.01 (Maret 2016):8295

Suci, E. S. T. (2009). Gambaran Perilaku Jajan Murid Sekolah Dasar di Jakarta. Jurnal Psikobuana,1(1), 29-38. Diakses dari Jurnal Ilmiah Psikologi Universitas Katolik Atma Jaya.

Triasari, R. (2015). Hubungan pengetahuan dan sikap mengenai jajanan aman dengan perilaku memilih jajanan pada siswa kelas V SD Negeri Cipayung 2 Kota Depok. [Skripsi]. Jakarta: Program Studi Keperawatan. Universitas Islam Negeri Syarif Hidayatullah.

Wahyuningsih, N.P. (2016). Pengaruh Media Visual Nutrition Card Terhadap Perubahan Perilaku, Perilaku dan Tindakan Anak Sekolah Dasar di SDN Keputih No.245 Surabaya. Media Gizi Indonesia, Vol 10, No 1 tahun 2015. Di unduh dari https://ejournal.unair.ac.id/MGI/article/view/3122p ada tanggal 9 Januari 2018.

Wang, Z., Zhai, F., Du, S., \& Popkin, B. (2008). Dynamic shifts in Chinese eating behaviors. Asia Pacific journal of clinical nutrition, 17(1).

Widiyaningsih, Endang Nur., Muwakhidah, Purwani Eni. (2018). Peningkatan Ketrampilan Pengelola Kantin Melalui Pelatihan Pembuatan Makanan Jajanan Sehat di SD Tiyaran 1 dan 3 Sukoharjo. The 7th University Research Colloqium 2018 STIKES PKU Muhammadiyah Surakarta.

Wulandari, Titin., Sudyasih Tiwi. (2016). Pengaruh Pendidikan Kesehatan Metode Visual AIDS Terhadap Sikap Tentang Jajanan Sehat Pada Siswa Kelas V di SDN Nogotirto Sleman Yogyakarta. [Skripsi]. Yogyakarta: Fakultas Ilmu Kesehatan. Universitas Aisyiyah.

Zulaekah, S. (2012). Pendidikan Gizi terhadap Perilaku Gizi dengan Media Booklet. Jurnal Kesehatan Masyarakat, 7(2), 127133. 